\title{
Dancing the Tightropes: Rhizoanalysis revisited
}

Mona-Lisa Angell monalisa@barnehageforum.no

Habitus AS

\section{Abstract}

The aim of my Master's thesis was to explore alternative concepts of anerkjennelse (recognition), hoping to expand the ways anerkjennelse could be thought and done in the field of Norwegian early childhood education and care. I used auto ethnographic methods in a Norwegian preschool and worked with rhizoanalysis as a strategy for reading the data. I wrote within a poststructuralist paradigm, influenced by a range of critical theories.

During and after this work, I was, and still am, haunted by the question: Was the (re)search rigorous enough to count as valid? The aim of this article is to linger a bit longer in that itchy state. Validity refers to the inferences drawn from the data, but the term validity is highly problematic after poststructuralism. Working within a poststructuralist paradigm of research, the intention was never to draw traditional inferences. What I did draw from the data was the readings done through rhizoanalysis, hence the task of this article: to revisit rhizoanalysis.

Key words: rhizoanalysis, validity issues, auto ethnography, recognition.

\section{Introduction}

If you don't like the game;

play it,

but play it differently, you ${ }^{1}$ said.

I was in Wonderland,

stuck,

and all the doors seemed too narrow

to fit the aim of my thesis

to explore and expand what recognition could be

and do in the field of Norwegian early childhood education and care. ${ }^{2}$

In this article I will revisit some of the methodology and validity issues I struggled with while I wrote my Master thesis. I used auto ethnographic methods following Denzin (2003) in a Norwegian preschool (I will elaborate later) and worked with rhizoanalysis (following MacNaughton, 2005; inspired by Deleuze \& Guattari, 1987) as a strategy for reading the data. I worked within a poststructuralist paradigm, influenced by a range of critical theories (for instance critical multiculturalism as discussed in May, 1999). During the time I wrote the thesis I dreaded my future examiners; I was afraid that my methodology choices would increase the chances of rejection. Yet

\footnotetext{
${ }^{1}$ The You of this story is Jeanette Rhedding-Jones. She told me this line numerous times.

${ }^{2}$ The italics mark a genre switch from non-fiction to fiction. I needed more tools than the professional language could offer, in order to put my journey into words. Hence, they are not quotes, even though I do juxtapose my experiences with the ones of Alice in Wonderland.
} 
passing did not seem to make the nagging feeling pass. I still worried someone might say this was not research. Not valid. The aim of this article is to linger a bit longer in this uncomfortable state.

\section{The issue of validity}

The term validity refers to the inferences drawn from the data. Hammersley and Atkinson (1983) stress the fact that data themselves cannot be valid or invalid, what is at stake is the inferences. Shadish, Cook and Campbell (2002:33) assert: "We use the term validity to refer to the approximate truth of an inference" (original italics). And so trouble emerges: Researchers drawing on poststructural theories, like I did, handle truth, and thus inferences, differently than the quote above suggests. Poststructuralist research makes meaning problematic and often even seeks to disturb and interrupt truths (Rhedding-Jones, 2005). Meaning is perceived as "deeply contextual and shifting, endlessly taken from other meanings which are taken from others, and so on" (Jones, 1997:265). The relentless movements of meanings create trouble when seeking to draw inferences.

A poststructuralist stance on truth should not be confused with relativism. Rather, it is an ethical desire to disturb normative, dominant knowledge in order to validate repressed or hidden knowledge (Lenz Taguchi, 2007:9). All the while keeping in mind that there is no position "outside"; poststructuralist research, like all research, (re)produces power relations (Lenz Taguchi, 2004).

There are different theories and practices regarding inferences in different research paradigms. What positivist researchers define as inferences might not be remotely close to anything poststructuralist researchers draw from their data. A brief glance at the main types of inferences in quantitative research might visualize this gap. According to Lund (2005) all research has to, in one way or another, deal with these four main inferences: statistical inferences (is the tendency significant or trivial?), causal inferences (does one variable cause the other?), construct inference (does the indicators measure the construct in question?) and generalizations (does this apply to other settings, groups and times etc. than the one measured?). Enderud (1984, in Sandvik, 2013), on the other hand, argues that the demands for reliability and validity is irrelevant for qualitative research.

In other words, validity is highly problematic within a poststructuralist paradigm. Lather (2007) has done groundbreaking work in an attempt to answer what she describes as a call for validity after poststructuralism. Legitimation of research after poststructuralism, she writes, "depends on a researcher's ability to explore the resources of different contemporary inquiry problematics and, perhaps, even contribute to "an 'unjamming' effect in relation to the closed truths of the past, thereby freeing up the present for new forms of thought and practice" (Bennett, 1990, p.277, in Lather, 2007:120). The purpose of doing research changes after poststructuralism. The goal is no longer to find or produce new truths; hence the ways of legitimating research is displaced too.

In her own words, Lather is making a scandal by reconceptualizing validity, transforming it into the unrecognizable. And she reinforces the scandal by proposing four alternative concepts of validity (she even adds checklists): ironic, paralogical, rhizomatic and voluptuous validity. Like Sandvik (2013) does in her doctoral dissertation, I will focus on rhizomatic validity, because it is most relevant to my work. Following Lather (2007), valid rhizomatic research is related to the ways of rhizomes (which I will describe in further detail later). Like rhizomes, rhizomatic research is more interested in networks and connections than hierarchies. Rhizomatic validity is achieved through striving to disturb dominant knowledge, and by resisting the temptation to create new generalizations and regimes of truth. This is done by supplementing and extending the status quo (Lather, 2007:125). I will come back to the validity question at the end of this article. But for now, let's go back to the beginning (if such a thing exists), in order to describe parts of the work I did and now question. 


\section{In the beginning there was...}

Anerkjennelse (recognition) was the first concept I learned when I started my education to become a preschool teacher. I noted that most of our teachers used the term frequently, and I remember thinking that anerkjennelse was probably something worth mentioning on most exams.

Anerkjennelse has various meanings in Norwegian, but in the ECEC field Professor Bae connected it to interpsychological theories (see for example Bae, 2005) in the 1980s, and practitioners and ECEC educators quickly embraced the idea.

A few years later I was doing a master degree in Multicultural and International Education. I had started to explore how cultural diversity was anerkjent (recognized) in a Norwegian preschool. I had undertaken auto ethnography following Denzin (2003) in a preschool which the teachers themselves called multicultural. Auto ethnography gave me the privilege to participate, and I chose to think of myself as an apprentice: I was there to learn, so I wanted to take part in whatever was on the agenda.

Most of the time I played with the children, talked with them, ate with them. Whenever they interacted with the teachers, I observed. But sometimes when they all went outside to play, I would stay inside to get a closer look at the rooms, walls, doors, and all of the things and toys that influenced whatever happened or didn't happen when the children and teachers populated these rooms.

I spent half the day in the preschool and half the day writing (during 16 days over a period of nine weeks), hoping to grasp some of the events of the day. Writing is perceived as a way of knowing even a way of being - by auto ethnographers (Foley, 2002:475). That made sense to me, while I wrote down my observations, feelings and whatever questions or troubling thoughts my experiences had brought forth that day. Sometimes writing would lead to decisions to take pictures of all the puzzles, read the children's books made available to them, and to count and describe all the clothes and footwear in the hall the next time I was going to the preschool. In the evenings, after spending the day in the preschool, I read. Poems, philosophy, policy documents, novels, an old diary from the time I was a student teacher during teaching practice in a preschool in Ghana for three months. And if it seemed important, I included pieces of it in the data material.

\section{The bricolour}

Amongst the inspirations for auto ethnographers are the movements in the 1970s where the researcher became a bricolour ${ }^{3}$, putting together texts and theories of different genres and fields (Denzin \& Lincoln, 2005:3). The researcher's task was not, at least within these movements, to make complete accounts and objective descriptions. The question was rather how the author could be present in the text while bringing forward multiple voices:

More than one voice can speak at once, in more than one tense. The text can be a collage, a montage, with photographs, blank spaces, poems, monologues, dialogues, voice-overs, and interior streams of consciousness (Denzin, 2003:87).

My material was certainly multivocal; at the time my living room floor was a collage of data spread out, moved around, and traced with post- its saying 'remember this and that'. And there where books. Piles of open books with writings in the margins, coupled together so that I could "see" what one author might have said to the other, had they actually met as their books did.

\footnotetext{
${ }^{3}$ In the French language the term is used "about using bricks to make another building" (Rhedding-Jones, 2005:123).
} 


\section{A crucial meeting}

The piles of books and collage of data resulted in many cross readings. And while reading across books on anerkjennelse and critical multiculturalism it happened: suddenly it was possible for me to grasp the obvious fact that there are several concepts of anerkjennelse besides the psychological one, and that some of them have been used extensively in discussions on critical multiculturalism. Up until then, I thought anerkjennelse had only one meaning within ECEC. The psychological interpretation of the concept was so dominant that I could feel my brain itch when I thought about it used differently. The juxtapositioning of different books had had an unjamming effect (c.f. Bennett, 1990 in Lather, 2007). And the effect bled into the data spread around on the floor.

Suddenly they were there, everywhere I turned, the lines of flight whispering with promise. I could see glints of alternative concepts of anerkjennelse everywhere. Anerkjennelse, I now thought, could be more than interpsychological matters; it could be political, cultural. Rereading anerkjennelse could interrupt the dominant discourse. Exploring alternative concepts of anerkjennelse could be a critical issue. And in that moment I decided; that would be the aim of my thesis. I was a student, caught between the desire to see where all these whispers might take me, and the need for my work to be stringent enough to be accepted by examiners. Wonderland, it seemed, needed structure, limits and logic in order to be accepted as valid research. Choosing a strategy for reading the data was crucial.

\section{Dancing the tightropes:}

Play it differently, you said.

- Don't walk!

No more looking down

Play it, you said.

Rigorous. Soft.

The twister will twist, whether you write it or not

\section{Bridging the gap}

That winter eight years ago the search led me to rhizoanalysis (MacNaughton, 2005); a poststructural approach to doing analyses. This was an analytic strategy that seemed to embrace Wonderland and go well with both auto ethnography and the aim of my thesis; to explore and expand the ways of doing and thinking anerkjennelse in Norwegian ECEC.

Rhizoanalysis, being an analytic approach inspired by poststructuralist thinking, can be done in many ways. "There are no recipes for creative analyses in this genre" the Danish Professor in social psychology Søndergaard (2002:187) states. Consequently, poststructuralist strategies are not presented as directly transferable techniques. In line with poststructuralist thinking, these analytic approaches are "meant to work as inspiration for other researchers in their methodological development of analytic tools" (Søndergaard, 2002:187). As mentioned in the discussion on validity; it is imperative for poststructuralist research to acknowledge truth and knowledge as political. "Thus, the poststructuralists' position on truth unsettles the value of rational and scientific thinking in creating freedom and equality", MacNaughton writes (2005:21). This radical position on truth and knowledge makes research within the paradigm of poststructuralism a risky business, hence doing work that will be accepted both by researchers "inside" and "outside" (not suggesting that paradigms has crisp boundaries) the paradigm is quite the balancing act.

MacNaughton (2005) writes within a poststructural paradigm. Thus, her description of rhizoanalysis is more an outline than an exhaustive methodology report. Following MacNaughton meant having to 
fill the gaps myself, and, with her writings as a starting point, elaborate and create my own way of doing rhizoanalysis. But this degree of creativity might not be accepted from a student. Students have to show that they have learned whatever the curriculum prescribes, and they do so by following someone else's work, not designing their own methodologies (Walkerdine, 1988). This doesn't just apply for master students. Sandvik (2013) puts it like this in her doctoral dissertation: Writing scientific texts one has to write in order for the text to be accepted within scientific discourses, which can sometimes feel like a struggle, "a dance with the imaginary wolves of theory and research" (p. 6) - "a disciplining force" (p. 5) (my translations).

\section{Messy logic}

"You are just playing cards", Alice said.

In Wonderland everything could shift

in a blink of an eye, and there was always more than one

meaning to everything said or done.

They were just playing,

and Alice thought there should be

no need to fear the punishing queen.

Also, they were just playing cards;

hence the queen too was just a decorated paper card,

and therefore nothing to be afraid of. Except,

how could one be sure

when the card queen started screaming "Off with their heads!"?

To me, doing research in early childhood education and care was Wonderland. It was magnificent, playful, scary and surprising. There was always more than one meaning to everything said or done, and the only thing I could be sure of was that something would change so that my imagined insights were unsettled. The only way not to go crazy was to adapt to whatever logic was in play.

Practitioners in ECEC know this, children know this; this is how the world of play and dreams work (Olsson, 2012). Doing research in Wonderland one has to cope with its messiness.

Wonderlands philosophical echo seemed to me to be found in rhizomatic logic, as described by Deleuze and Guattari (1987). They bring forward the rhizome as a way of grasping and building knowledge, contesting the tree of knowledge.

The model of the tree has been used to illustrate the modernist understanding of knowledge as something that has to be built from the bottom up (Lather, 2007:124). In this paradigm, knowledge, and hereunder language, is hierarchical with its roots, trunk and top. For instance you need a solid understanding of a concept (root) before you can use the word (trunk) correctly, and when you do, you might add nice adjectives or use the word in refined ways (branches and leaves). But then what? How is this connected to all the other words and sensations and experiences you have had, to all your knowledge and all the quirky ways you braid them together? The model is a tree, not several trees or a forest with lots of trees and other beings. So "thought lags behind nature", Deleuze and Guattari states (1987:5). 


\section{Connections and heterogeneity}

Rhizomes, on the contrary, are "systems with underground stems and arial roots, whose fruits are tubers and bulbs" (Lather, 2007:124). They are anti-authoritarian in their lateral growth (Deleuze \& Guattari, 1987). The aim is not to rise up, but to connect and expand: "Any point of a rhizome can be connected to any other, and must be", Deleuze and Guattari writes (1987:7). The ways of the rhizome made it possible for me to make use of the collage of data spread out on my living room floor. When done using rhizomatic logic, knowledge building would be strengthened by the heterogeneity of my material. Both auto ethnography, following Denzin (2003), and rhizomatic logic, following Deleuze and Guattari (1987), supported the juxtapositioning of poems and policies, field notes and photos, and that the bits and pieces should be allowed to change each other.

A rhizome is always changing, and all of its lines and ruptures and connections are altered simultaneously, Deleuze and Guattari (1987) write, which leads us to decalcomania. The rhizome is a map, Deleuze and Guattari emphasize, not a tracing: "The map is open and connectable in all of its dimensions; it is detachable, reversible, susceptible to constant modification [...] It is itself part of the rhizome" (Deleuze and Guattari, 1987:12). In other words: as long as research needs to be written and published as static, irreversible texts, scientific knowledge building may, at its best, tap into and vaguely resemble rhizomatic logic.

But messy logic set aside: I acknowledged the fact that keeping track of my various data material might be a confusing act for anyone not as involved in it as I was at the time. Hence I made overviews of it that I attached to the thesis. One list was a short outline of the eleven kinds of data material I had put to work ${ }^{4}$. The other list consisted of the 37 texts selected from the data material and used in the rhizoanalysis. This way I hoped to make the data available to readers, so they could follow my thinking when I built rhizomes, but also, in the unlikely - yet desirable - event of anyone finding it interesting enough, they might build rhizomes of their own by connecting some of the excerpts with texts outside my data material.

\section{Building the building}

I will now make a brief outline of rhizoanalysis as a poststructuralist strategy for reading data, focusing on the choices I made to prepare the rhizoanalysis. Thereafter I will use one rhizoanalysis that I undertook, in order to illustrate how I carried out the analysis. According to MacNaughton (2005) rhizoanalysis consists of both deconstruction and reconstruction, and they always start with the deconstruction of a text. MacNaughton (2005) writes that the first text should be a text that you find disturbing and therefore want to explore. I gathered all the texts I felt this way about.

I struggled with choosing the second text, the text that would, according to MacNaughton (2005), start the reconstructing part of the rhizoanalysis where the text is connected to other texts. If the purpose was merely to build rhizomes, any text from the data material would do. But the bridge from deconstruction to reconstruction would decide the directions the rhizoanalysis might take, and therefore was a crucial part of the rhizoanalysis.

As this choice was not something MacNaughton (2005) discussed in depths, I turned to Deleuze and Guattari hoping to find something there to lead the way. Deleuze and Guattari (1987) write that

\footnotetext{
${ }^{4}$ Field notes in a journal written after each visit to the Norwegian preschool, field notes written in the preschool on whatever paper and with whatever writing utensils available there, internal policy documents for the preschool regarding new children attending the preschool, internal policy documents for the preschool regarding the five-year-olds going to school the next fall, an annual plan, a handmade list of the content of the children's bookshelf and pictures of the books, 42 photos of the rooms and materials there, an outline I drew of the shapes of the bead boards, two party invitations; one for Eid and one for the Vietnamese new year, 34 photos of puzzles and lotto-games, and excerpts from my private journal from the time I was a bachelor student and traveled alone to a fishing village in Ghana for teaching practice in a preschool.
} 
rhizomes grow from middles. This made sense to me. Theories on poststructuralism and critical multiculturalism often resist centers, but middles in the Deleuzian and Guattarian way were different. Even in messy Wonderland something significant sets things going, for instance a stressed out, talking rabbit carrying a watch: The rabbit might not be the most important part of the story, but it certainly accelerates it.

The aim of my thesis was to explore what anerkjennelse could be and do in Norwegian ECEC, so I chose definitions of anerkjennelse as middles and acceleration points for my rhizoanalysis. Because I did not want to dismiss the dominant truth about anerkjennelse in Norwegian ECEC and replace it with another, I wanted to explore more than one alternative definition. I figured three definitions would be a limited enough amount to give the work structure, and a rich enough amount to form an exploration and hopefully expand the possible ways of thinking and doing anerkjennelse in Norwegian ECEC. Thus the first texts of the rhizoanalysis also would amount to three, and I chose the three that seemed to connect with anerkjennelse.

I selected the three concepts of anerkjennelse (to introduce the deconstructive part of each rhizoanalysis) following these three criterions: 1 ) they were rarely used (explicitly) in Norwegian ECEC 2 ) they were used extensively in discussions on multicultural education 3) they had been put to use by some researchers in a Nordic country. Each of the three definitions of anerkjennelse led me to a place where it was possible to explore how that term might disturb and expand thoughts and practices in Norwegian ECEC.

\section{An alternative rhizome of anerkjennelse}

I will use parts of the first rhizoanalysis to illustrate how the rhizome was built. In this rhizome I was exploring anerkjennelse (recognition) read as a political strategy. This is a common term within political science, and one of the most important concepts in newer political theories (Gressgard, 2007:10). It is used for instance when a country's government chooses whether to recognize areas, like Palestine, as a state, or to recognize minority groups, like the Sámi people, as indigenous.

This kind of anerkjennelse often generates group rights (for instance to preserve and develop a minority language, traditions and cultural identities), also within the educational system. Hence, it is important to the field of multicultural education. One of the main issues discussed in relation to this concept of anerkjennelse is that even if the rights are desirable, they come with a range of dilemmas. One of these dilemmas is that in order to give the group rights, the group in question has to communicate a recognizable group identity. Group identities are, according to Kincheloe and McLaren (2005), domains of struggle. They are not static, but "postulated, asserted, and then filled with prescriptive norms by people with interests" (Baumann, 1999:115). In other words, anerkjennelse has the force to liberate and coagulate - simultaneously.

I started the rhizome with a text excerpt from the preschool's own annual plan, which was filled with descriptions of their pedagogical plans and ideals:

"Lingual, cultural and religious diversity is a resource and strengthens the community of the preschool. We facilitate equal dialogue and interaction between different groups. We talk about both what is different and common. When children meet different cultures and traditions, this lays the foundation for respectful interaction. It is the staff's responsibility to make sure all the children and parents are equal and treated with the same degree of understanding and respect. [...] Our work strengthens both the children's mother tongue and the Norwegian language. We have bilingual teaching assistants and arrange language activities in small groups. Through this we give the children the opportunity to master both language and develop their double cultural identity."

Following MacNaughton (2005), I divided the text into named fragments. This could have been done in many ways. I chose to divide this particular text into five fragments (whilst knowing that there are many more fragments and meanings in the text), all bringing some kind of information to the table: 
i. Lingual, cultural and religious diversity is a resource.

ii. The preschool facilitates equal dialogue between groups.

iii. The preschool supports bilingualism through having bilingual teaching assistants and arranging language-activities in small groups.

iv. Children have the opportunity to develop a "double cultural identity".

v. The staff is responsible to make sure that all the children and parents are treated equally.

Thereafter, I began to untangle the text through reading the fragments individually and together. Following MacNaughton (2005) I searched for connections and ruptures, key characteristics of the rhizome (Deleuze \& Guattari, 1987). I will not provide an exhaustive report of the readings I did, instead I will give an example. I saw connections across the fragments linked to equality: the children are treated equal, the dialogues are equal, different languages, cultures and religions are equal (in the sense that they are all defined as resources). Simultaneously, there were embedded ruptures: does equality mean sameness? Or does equality point to equal status? When is equality sameness and when is it equal status? Who does the sameness regard, and who gets the equal status - from whom?

The second step of the rhizoanalysis was connecting the threads and fragments of the first text to a concept of anerkjennelse. According to Gressgård (2007) this concept includes booth demanding individual equality (generating universal rights, e.g. "every child has the right to..."), and demanding anerkjennelse of the distinctive characteristics of groups and individuals (generating group rights, e.g. "Sámi children have the right to..."). Anerkjennelse implies normative assessments of cultural practices; Gressgård writes (2007:14). In Norwegian ECEC this term of anerkjennelse calls for discussions on whose knowledge, values and skills are taken into consideration when the staff think and do their practices (Angell, 2011). The issue now was: How might this concept of anerkjennelse connect to the fragments of the annual plan?

I started the connection-work (reconstructions) by reading the excerpt from the annual plan looking for traces of individual equality. This was especially evident in fragment $v$, where the wording was: "all the children and parents are equal". In the annual plan they elaborated: All the children and parents "are treated with the same degree of understanding and respect". Political anerkjennelse, read as individual equality, was already there. And working side by side with it, was anerkjennelse read as recognition of distinctive characteristics of groups, in fragment iii og iv, declaring efforts towards strengthening the children's bilingualism and what they call double cultural identities.

Further, cross-reading the fragments of the annual plan with this concept of anerkjennelse generated thoughts on the mess I described earlier on: sameness / equal status / difference / equality etc. At first it appeared chaotic, like the author(s) should have worked a bit more to make it neat, clear. I started by thinking that the authors should have begun with the declaration that all individuals are different and yet of equal status, and then written about the group level and group rights. I was interrupted by how critical multiculturalism shows some of the traps of this concept of anerkjennelse; identities - both individual and group identities - are slippery, always changing, and they are domains of struggle (c.f. Baumann, 1999). Maybe tidying up the annual plan could give force to the coagulating ways of identities?

The third step in my rhizoanalysis was questioning the rhizome (so far) in relation to its sociopolitical context. This step was inspired by discussions MacNaughton (2005) offered through her rhizoanalysis, but also grounded in the critical theories on critical multiculturalism that I put to work throughout the thesis. Here the sociopolitical context is perceived as crucial and, therefore, should always be taken into account (May, 1999). "Sociopolitical context" is a wide term, so I chose three strands to draw connections with: 
1) The national policy on increasing the number of bilingual children attending preschool (which is not mandatory in Norway). The goal is to decrease the number of children starting school not speaking Norwegian "well enough".

2) The major changes in national policy on hiring (and funding the salary for) bilingual staff in preschools in 2004. The changes had resulted in fewer owners hiring bilingual staff, and children having differing rights depending on which county their preschool was in (Angell, 2011).

3) The 1996 national framework plan for preschools, where it emphases that the preschool should be a "bridge builder" between groups, and between minority groups and the majority. The 2006 version of the framework plan does not describe this as a task for preschools.

The last and most extensive step in my rhizoanalysis was connecting it to the data material to create ruptures and connections to whatever the rhizome had become at the time. The first text I engaged was from my field notes:

"Shilan's parents came to talk to Anita, the teacher in charge of the unit Shilan attends. Afterwards Anita told me that the parents demanded that the preschool hired a bilingual assistant for Shilan. Shilan speaks three languages; Kurdish, Arabic and Norwegian. Anita says Shilan's parents are worried because she switches between languages at home. They want a bilingual assistant who knows all three languages. Anita asked me: 'Do they have the right to bilingual assistance?' (Field notes, 11. Oct. 2006)

One connection here is the question of rights: Who, if any, has the right to bilingual staff? I connected this to the sociopolitical context, to the policies and legislations, and to the ruptures and connections within those. Further, I connected Anita's story to group rights, and their liberating and coagulating ways. Another connection could be made to the preschool annual plan. In addition to being a plan and tool for the staff, it communicates to parents what they can expect from the preschool. Maybe Shilan's parents' wishes were partly related to both the annual plan, stating that they have bilingual assistants, and the national policies working towards bilingual children attending preschool in order to learn Norwegian?

The next text I connected to the rhizome was Naomi Shishab Nye's (1995) poem Over the fence, where the last verse goes like this:

\author{
You say I'm lucky to know \\ two languages. What good are two words \\ if no one can hear them? \\ I'd take one tongue if it fit me, \\ I'd wear it like the postman \\ wears his suit, so people know \\ what he is doing in the world. \\ Walk up and down the street \\ delivering smiles. \\ I say no one is lucky. \\ We have faces, they get old. \\ (Nye, 1995: 152-153)
}

I will leave the rhizome there for others to pick up. In my thesis I connected it to ten more texts (Angell-Jacobsen, 2008). And I treated the other two alternative concepts of anerkjennelse the same 
way, building rhizomes through making connections between texts that had emerged from this particular preschool, the sociopolitical context is was part of, the alternative concept of anerkjennelse in question, and a range ${ }^{5}$ of other texts of different genres. Every time I added a new text it changed the whole rhizome in numerous ways, more ways than I was able to pursue. By letting a text connect to the rhizome it did not only change the directions the growth of the rhizome was taking at that particular point, but also all the previous texts I had added to the rhizome, the discussions I had done in relation to all of them and the ones I had neglected to do - and the connections between them all.

Needless to say, the three rhizoanalyses I did were merely incomplete maps of rhizomes - of the ways anerkjennelse could be thought and done in Norwegian ECEC. Grasping the magnitude of a rhizome and describing it is like trying to paint the whole universe at once. Research can be inspired by rhizomatic logic, but because it has limits of time, space, and discourses on science - not to mention the researcher's capacities - research is never able to more than resemble the rhizomatic nature of knowledge. In rhizomatic logic there is no point trying to grasp the whole universe, as it is constantly changing and will never be the same.

\section{Living the doubts}

In high school I had an art teacher who told me I should not draw faces until I knew how. He wanted me to practice it all first: the structures, textures, dimensions, the in-betweens. He strongly believed in learning the rules first in order to fully understand how and when to break them. I imagine he would find rhizoanalysis and its relentless rule breaking to be something you should restrain from doing until you have plenty of experience from more traditional methodologies. Maybe he was right. After all rhizoanalysis involves being creative, living with nagging fears, avoidance of hard facts, use of low status data and, in the end, ending up with nothing more than deficient maps of knowledge. To do all this rule breaking and still end up drawing a face is difficult, no doubt. But then again, maybe it is entirely possible to learn rules and break them simultaneously.

I set this article going by asking: Was the work I did rigorous enough to count as valid research? The answer needs to be shaped as a question: "How exploratory and creative can research methodology be before it ceases to be research methodology?". Or simply: "What is research?". Professor Rhedding-Jones chose this exact title for her 2005-book. Her initial answer to the question is that research is to search and to search again - and again. In other words, the prefix "re" is as important as the term "search". In that sense, rhizomatic logic can easily find a home within the limits of research. Rhedding-Jones' (2005) next answer is more of a multiplicity; the whole book consists of different answers to the question in terms of paradigms, methodologies, philosophies and epistemologies.

In my thesis I drew on Lather's (2007) reconceptualization of validation, and argued that my work could be legitimized as valid - in the rhizomatic sense. I did not draw traditional inferences from the data; hence evaluating the work through traditional concepts of validity would be pointless. Maybe the most fruitful conclusion to such a mission impossible would be that poststructuralist research is not science - at least in the sense that the founders of theories on inferences, and thus validity, did in the mid nineteen hundreds (Lund, 2005). But, then again, would research focused on drawing causal inferences, for instance, be legitimized through concepts of validity after poststructuralism?

Sandvik (2013) writes that even though rhizomatic validity is relevant to her work, it feels like a paradox to legitimize research by these criterions. I read this as a resistance towards making new truths, new grounds to rest on. Maybe the scandal Lather (2007) makes by conceptualizing validity is both inside and outside poststructuralism? Indeed, poststructuralism, with its relentless motions and rule breaking, is not a field made for resting. Maybe the nagging fear I had that someone would "out"

\footnotetext{
${ }^{5}$ More specifically; fifteen, thirteen and nine texts.
} 
my work as not scientific enough, grew out of a lacking understanding of all of the research paradigm involved in that string of thought. Or maybe there is cowardice hidden in the resistance towards drawing explicit inferences - possible to critique. Or maybe validity is dead. For now I will have to go with Honan (2004) who writes that an important task for a researcher is to decide what to leave undone for others to take further.

\section{Afterword}

Professor Jeanette Rhedding-Jones is the "you" of this article. Our first conversation was when I begged her to supervise on my master's thesis. She didn't know me, but I felt I knew her through her writings.

After a year of struggling alone with decoding the similar, yet significantly differing discourses in the early childhood education and care program that I, being a preschool teacher, was familiar with, and the Masters programme I was doing in multicultural and international education, I knocked on her door. I described my conclusions so far: that the words used in the two courses were the same, but the meanings were not. That the philosophers taught were the same, but the readings of them differed. Research methodologies which appeared important in ECEC at the time, for instance reconceptualising and decolonizing work, were never mentioned in the courses I was taking. ECEC itself was never a topic. But worst of all: during this past year I had yet to figure out what was expected of a Master's thesis.

I told her I wanted to do a thesis on Norwegian early childhood education and care and multicultural education, and that she was the only professor who knew both fields. She took on the extra workload and this became the first of many conversations about how I needed to find ways of doing research and writing that might meet the criterions of what was thought to be a good Master's thesis in both (dis)courses. I will be forever grateful that she wanted to be my companion on this journey. I wrote this to you, Jeanette. Thank you for believing I could dance.

\section{References}

Angell, M.-L. (2011). «Anerkjennelser av kultur i barnehager», in Barnehagepedagogiske diskurser. A. M. Otterstad \& J. Rhedding-Jones (eds) (p. 200-214). Oslo: Universitetsforlaget.

Angell-Jacobsen, M.-L. (2008). Anerkjennelse av kulturelt mangfold i barnehager: Rekonseptualiseringer av "anerkjennelse" ved hjelp av (auto)etnografi og rhizoanalyser. HiO-masteroppgave nr. 7. Oslo: Oslo University College.

Bae, B. (2005). Troubling the identity of a researcher. Methodological and ethical questions in cooperating with teacher-carers in Norway. Contemporary Issues in Early Childhood, 6(3) p. 283-291.

Baumann, G. (1999). The Multicultural Riddle: Rethinking national, ethnic, and religious identities. New York and London: Routledge.

Deleuze, G. \& Guattari, F. (1987). A thousand plateaus: Capitalism and schizophrenia. Translation: Massumi, B. Minneapolis / London: University of Minnesota Press.

Denzin, N.K. (2003). Performance Ethnography: Critical pedagogy and the politics of culture. California, London \& New Dehli: Sage Publications. http://dx.doi.org/10.4135/9781412985390 
Denzin, N.K. \& Lincoln, Y.S. (2005). "Introduction: The discipline and practice of qualitative research", in Handbook of Qualitative Research (3.ed.). N.K. Denzin \& Y.S. Lincoln (eds). (p. 1-32). Thousan Oaks: C.A. Sage.

Foley, D.E. (2002). "Critical Ethnography: The reflexive turn". Qualitative Studies in Education. 15(5), p. 469-490. http://dx.doi.org/10.1080/09518390210145534

Gressgård, R. (2007). “Anerkjennelse: Hvilke forskjeller er relevante?”. Norsk tidsskrift for migrasjonsforskning. 1, p. 10-26.

Hammersley, M. \& Atkinson, P. (1983). Ethnography: Principles in practice. London: Travistock.

Honan, E. (2004). “(Im)plausibilities": A rhizo-textual analysis of policy texts and teachers' work. Educational Philosophy and Theory. 36(3), p. 267-281. http://dx.doi.org/10.1111/j.1469-5812.2004.00067.x

Kincheloe, J.L. \& McLaren, P. (2005). "Rethinking Critical Theory and Qualitative research", in Handbook of Qualitative Research (3.ed.). N.k. Denzin \& Y.S. Lincoln (Eds). (p. 303342). Thousand Oaks: C.A. Sage.

Jones, A. (1997). "Teaching Post-Structuralist Feminist Theory in Education: Student resistances". Gender \& Education. 9(3),261-269. http://dx.doi.org/10.1080/09540259721240

Lather, P. (2007). Getting Lost: Feminist efforts toward a double(d) science. Albany: State University of New York Press.

Lenz Taguchi, H. (2004). In på bara benet: En introduction till feministisk poststrukturalism. Stockholm: HLS Förlag.

Lenz Taguchi, H. (2007). "Deconstruction and Transgressing the Theory: Practice dichotomy in early childhood education". Educational Philosophy and Theory. 3, p. 275-290.

Lund, T. (2005). "The Qualitative- Quantitative Distinction: Some Comments." Scandinavian Journal of Educational Research. 49(2), p. 115-132.

http://dx.doi.org/10.1080/00313830500048790

MacNaughton, G. (2005). Doing Foucault in Early Childhood Studies: Applying poststructural ideas. London and New York: Routledge. http://dx.doi.org/10.4324/9780203465332

May, S. (ed.) (1999). Critical Multiculturalism: Rethinking multicultural and antiracist education. London and Philadelphia: Falmer Press.

Olsson, L. M. (2012). Eventicizing Curriculum: Learning to read and write through becoming a citizen of the world. Journal of Curriculum Theorizing. 28(1), p. 88-107.

Rhedding-Jones, J. (2005). What is Research? Methodological Practices and New Approaches. Oslo: Universitetsforlaget.

Sandvik, N. (2013) Medvirkning og handlingskraft I småbarnspedagogiske praksiser: Horisontalt fremforhandlet innflytelse. Doctoral dissertation. Norges teknisk-naturvitenskapelige universitet: Trondheim, Norway.

Shadish, W.R., Cook, T.D \& Campbell, D.T. (2002). Experimental and Quasi-experimental Designs for Generalized Causal Inference. University of Michigan: Houghton Mifflin.

Søndergaard, D. M. (2002). "Poststructuralist Approaches to Empirical Analysis". Qualitative Studies in Education. 15(2), p. 187-204. http://dx.doi.org/10.1080/09518390110111910

Walkerdine, V. (1988). The Mastery of Reason: Cognitive development and the production of rationality. London: Routledge. 